Tommaso Visone

Scuola Superiore Sant'Anna, Italy

\title{
FACING NIHILISM. CAMUSIAN ROUTE TO RESHAPE POLITICS
}

The government of persons is replaced by the administration of things...

Friedrich Engels, Anti-Dühring (1878)

\begin{abstract}
S'il n'y a pas de nature humaine, la plasticité de l'homme est, en effet, infinie. Le réalisme politique, à ce degré, n'est qu'un romantisme sans frein, un romantisme de l'efficacité.
\end{abstract}

Albert Camus, L’homme révoltén (1951)

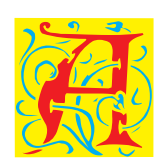

ccording to Jürgen Habermas, Europeans are living inside a "technocratic spiral". "New Old World" politics seems to be characterised by the recurring exclusion of democratic solutions in favour of technical and intergovernmental ones. All these choices are legitimated with an idea of "efficacy" and "pragmatism" that implies that the chosen "technical" policy is the "less evil" one in order to politically "survive", without giving any other reason to legitimise the voluntary and progressive erosion of people's participation. Until now it has been useless to underline that such a praxis that has, with its discourse, created within the electorate a sort of hate and disgust towards reasoned politics and the same establishment. A hostility that can feed populism, mistrust, and isolationism (as the Brexit vote showed). The main "solution" to growing "revolutionary" impulses within the electorate is still found in a pragmatic and technically inspired "agreement" or imposition out of any democratic representation. From this point of view the winner-the national executives in this case-is always right: no matter if they are authoritarian or against the more essential rules of liberal democracy or human dignity. Surviving as the true son of the supposed "end of ideologies", this kind of "realism" is_-as shown 
by Albert Camus-intrinsically nihilist since it leads directly to pure "political cynicism", or the idea that the only thing that matters is to take and manage power whatever the cost. Following this, it is possible to arrive at sacrifier les autres, as the recent migrant crisis has sadly shown us. Against such an attitude Camus underlines how it is fundamental to re-affirm a living measure- the ability of men to create and introduce a defined meaning inside history-and to struggle to maintain a continuous tension among realism and morality. From this point of view the Franco-Algerian writer stresses the importance of Art as educational tool that introduces the exigency to choose inside the "reality", to refuse a part in order to give form to the other. Within this movement that, preserving human nature, says simultaneously "no and yes" it is possible finally to find, according to Camus, our route to reshape politics.

A characteristic of nihilism is, according to Camus, the idea that "everything is possible/licit" and, starting from that, society develops a true indifference pour la vie. Paradoxically such a social attitude is built upon the religious, sacralised, reaction to the absurdity of life, the impuissance a croire in a defined meaning. It is not the absence of belief, but the conscious or unconscious construction of absolute and totalizing belief that closes any possibility to face the truth. From this point of view, nihilism is the son of the absurd condition of man: in order to refuse absurdity, human beings created an absolute that gives a fully, closed (and, as it is closed, false), sense of the world. To say it in Camusian Nietzsche logic — which, according to Camus, was the first to have a consciousness about nihilism — "le nihiliste n'est pas celui qui ne croire à rien, mais celui qui ne crois pas à ce qui est."1

The same Nietzsche, following the argumentation of the Rebel, ended with a "deification of fatality" (and of the consequent "will of power") — to accept to be as one is, avoiding the will to change ourselves and transform the condition of society-in order to emerge from the situation of total absurdity, described by the German philosopher as the moment in which it affirmed the need to recognise the fatality of the earth as the truth. ${ }^{2}$ Contemporary nihilism is thus, in Camus' words, a new religious reaction to human, the condition that-using the instruments of philosophy (which returns to theological concepts, such as Marxism) and considering the historical bankruptcy of Christianity-force

\footnotetext{
1 A. Camus, L’homme révolté, Paris: Gallimard, 1951, 96.

2 See Ibidem, 100.
} 
humanity to sacrifice itself and its truth to avoid facing it. ${ }^{3}$ It is "moral" in its deepest sense: in that it renounces the difficult but virtuous and true tension of life to institute a total solution, end, belief. These new religions, in more detail, are Biology, History and — at the very end—pure Power/Fact. If the first two are the direct expression of 19th century civilisation, the last is their consequence. In effect the cult of "immanence" - biological diversity or historical processends with the absolute exaltation of the existing Power, of what is the expression and motor of reality. To echo Alexandre Kojève, the true "Hegel" fought by Camus:

what is good is what exists, to the extent that it exists. All action, since it negates existing givens, is thus bad: a sin. But sin can be pardoned. How? Through its success. Success absolves crime, because success is a new reality that exists. ${ }^{4}$

There is no possibility of independent human judgement, no value that can be used to criticise what it is. From this point of view, the religion of History becomes the religion of the mere "fact", of the pure, and self-legitimising, strength. As Camus wrote, criticising revolutionary Marxist thought, this reactionary apology of the fact lead to political cynicism as the main effect of contemporary nihilism: ${ }^{5}$

3 On the relationship between nihilism and theology in the thought of Camus, see M. Sharpe, Camus Philosophe. To return to our beginnings, Leiden/Boston: Brilll, 2015, 98-145.

${ }^{4}$ A. Kojève, Introduction à la lecture de Hegel, Paris: Gallimard, 1947, 95. About Camus as critic of Kojève, see P. Sabot, Les mésaventures de la dialectique. Camus critique de Kojève dans "L'Homme révolté", in: D. Lyotard (ed.), Albert Camus contemporain, Presses Universitaires du Septentrion, Villeneuve d'Ascq, 2009, 45-60.

5 "If, in fact, to ignore history becomes the same as denying reality, it is still alienating oneself from reality to consider history as a completely self-sufficient absolute. The revolution of the twentieth century believes that it can avoid nihilism and remain faithful to true rebellion, by replacing God with history. In reality, it fortifies the former and betrays the latter. History in its pure form furnishes no value by itself. Therefore one must live by the principles of immediate expediency and keep silent or tell lies. Systematic violence, or imposed silence, calculation or concerted falsehood become the inevitable rule. Purely historical thought is therefore nihilistic: it wholeheartedly accepts the evil of history and in this way is opposed to rebellion. It is useless for it to affirm, as compensation, the absolute rationality of history, for historical reason will never be fulfilled and will never have its full meaning or value until the end of history. In the meanwhile, it is necessary to act, and to act without a moral rule in order that the definitive rule should one day be realized. Cynicism as a political attitude is only logical as a function of absolutist thought; in other words, absolute nihilism on the one hand, 
One of Hegel's commentators, Alexandre Kojeve, of left-wing tendencies it is true, but orthodox in his opinion on this particular point, notes Hegel's hostility to the moralists and remarks that his only axiom is to live according to the manners and customs of one's nation. A maxim of social conformity of which Hegel, in fact, gave the most cynical proofs. Kojeve adds, however, that this conformity is legitimate only to the extent that the customs of the nation correspond to the spirit of the times-in other words, to the extent that they are solidly established and can resist revolutionary criticism and attacks. But who will determine their solidity and who will judge their validity? For a hundred years the capitalist regimes of the West have withstood violent assaults. Should they for that reason be considered legitimate? Inversely, should those who were faithful to the Weimar Republic have abandoned it and pledged themselves to Hitler in 1933 because the former collapsed when attacked by the latter? Should the Spanish Republic have been betrayed at the exact moment when General Franco's forces triumphed? These are conclusions that traditional reactionary thought would have justified within its own perspectives. The novelty, of which the consequences are incalculable, lies in the fact that revolutionary thought has assimilated them. The suppression of every moral value and of all principles and their replacement by fact, as provisional but actual king, could only lead, as we have plainly seen, to political cynicism $[\ldots]^{6}$

In the very end, to believe in History results in believing in force, in the simple ability to impose a reality (to make things work, no matter how or why), but such faith is the most nihilistic of all because, as it was well understood by Rousseau, it is impossible to create a social meaning around mere force. ${ }^{7}$

How to face such a philosophy — with its inherent social attitude-avoiding a return towards a classic religious/theological approach? ${ }^{8}$ It was Camus's contention that it is necessary to start from a fundamental truth. Confronting himself with Nazism, the author of the Myth of Sysifus arrived at the notion to individuate an element that allows itself to build meaning starting from the absurd condition of life:

absolute rationalism on the other. As for the consequences, there is no difference between the two attitudes. From the moment that they are accepted, the earth becomes a desert". A. Camus, L'homme révolté, Paris: Gallimard, 1951, 360-361. Each translation from the French editions is made by the author of this essay.

${ }^{6}$ A. Camus, L’homme révolté..., 185.

7 "Force is a physical power, and I fail to see what moral effect it can have. To yield to force is an act of necessity, not of will -- at the most, an act of prudence. In what sense can it be a duty?" J.-J. Rousseau, Du Contrat Social, ou principes du droit politique, Amsterdam: Metalibri, 2008, 13.

8 That is the classic way of authors such as Augusto del Noce and, in a different way, Massimo Cacciari. See A. del Noce, Il suicidio della rivoluzione, Roma: Aragno, 1978 e M. Cacciari, Il potere che frena, Milano: Adelphi, 2013. 
I, on the contrary, chose justice in order to remain faithful to the world (la terre). I continue to believe that this world has no ultimate meaning. But I know that something in it has a meaning and that is man, because he is the only creature to insist on having one. This world has at least the truth of man, and our task is to provide its justification against fate itself. And it has no justification but man; hence he must be saved if we want to save the idea we have of life. With your scornful smile you will ask me: what do you mean by saving man? And with all my being I shout to you that I mean not mutilating him and yet giving a chance to the justice that man alone can conceive. ${ }^{?}$

Man is the only being that pretends justice. He is the only being that refuses injustice, to be as it is, ${ }^{10}$ the same absurd condition to attempt to build something other. He is the only being who can say no to what exists, and also to his same life, because his priority is linked to the reason of his life. ${ }^{11}$ And-through such a capability-Camus finds a dynamic and living element that characterises the human being: the possibility to revolt, to be an existential and political rebel. And such an element-without being a transcendental element-is not a historical one. It is a constant possibility of man that could be manifested only inside history/reality, as the only opportunity that man has, without coinciding exactly with it. As he wrote in The Rebel:

History, necessary but not sufficient, is therefore only an occasional cause. It is not absence of values, nor values themselves, nor even the source of values. It is one occasion, among others, for man to prove the still confused existence of a value that allows him to judge history. Rebellion itself makes us the promise of such a value. Absolute revolution, in fact, supposes the absolute malleability of human nature and its possible reduction to the condition of a historical force. But rebellion, in man, is the refusal to be treated as an object and to be reduced to simple historical terms. It is the affirmation of a nature common to all men, which eludes the world of power. History, undoubtedly, is one of the limits of man's experience; in this sense the revolutionaries are right. But man, by rebelling, imposes in his turn a limit to history, and at this limit the promise of a value is born. ${ }^{12}$

9 A. Camus, Lettres à un ami allemand [1945], in: A. Camus, OEuvres, Gallimard, 2013, 476.

10 "Man is the only creature who refuses to be what he is". A. Camus, L'homme révolté..., 24.

11 See the dialogue between Diego and La Peste in A. Camus, L'état de siège [1948], in: A. Camus, OEuvres Complètes, 766.

12 Ibidem, 311. 
Thus, such an affirmation of a "common human nature" through revolt goes directly against the nihilism of the religion of power. In fact it destroys the point on which the contemporary cult of the "is right as it is" found its theoretical strength: the absence of a non-transcendental criterion to judge reality. ${ }^{13}$ The point is clear to Camus who sometimes used the expression "human nature" to underline such a turning point. "If there is no human nature, then the malleability of man is, in fact, infinite. Political realism, on this level, is nothing but unbridled romanticism, a romanticism of expediency." 14

The interesting point of such a Camusian approach is that it does not underline any substantial character of "human nature", identifying it just with a possibility that is unique within the universe: to give meaning and justice to a differently absurd and silent reality. Only a human can try to feel and do something like that. But-and that is the core point of The Rebel-it must be done while respecting himself, his unique dignity, and the limits that this same capability impose upon him. He cannot-in order to create justicedestroy the world or human dignity and life. He cannot transform humans into objects because humans, different from objects, are capable of saying no, to be moral actors inside the reality. From this point of view, to revolt is in itself a "measure" in a double way: first, it potentially acts against the religious (which aspires to totalise everything) approach to reality, against the dominion of man over man and against the menace to destroy human dignity, and second, it is in itself a theoretical criterion to judge the same reality. To put the latter point differently: it is fundamental to fight to preserve the possibility of man revolting, fighting in order to respect such a fundamental dignity and do what is possible to allow to it to explicate in a non-totalitarian way its attitude towards justice. ${ }^{15}$ According to Camus, in fact, "it is true that we cannot

13 "La Révolte" creates a value that goes beyond the same individual. See A. Camus, Remarques sur la Révolte, in: Aa. Vv., L'existence, Gallimard, 1945, 11-13.

14 Ibidem, 297.

15 "Far from demanding general independence, the rebel wants it to be recognized that freedom has its limits everywhere that a human being is to be found-the limit being precisely that human being's power to rebel. The most profound reason for rebellious intransigence is to be found here. The more aware rebellion is of demanding a just limit, the more inflexible it becomes. The rebel undoubtedly demands a certain degree of freedom for himself; but in no case, if he is consistent, does he demand the right to destroy the existence and the freedom of others. He humiliates no one. The freedom he claims, he claims for all; the freedom he refuses, he forbids everyone to enjoy. He is not only the slave against the master, but also man against the world of master and slave". Ibidem, 355. 
'escape History', since we are in it up to our necks. But one may propose to fight within History to preserve from History that part of man which is not its proper province." 16

Such a philosophy has its political and educational effects. It implies, politically, to act following the rule of measure that affirms:

When the end is absolute, historically speaking, and when it is believed certain of realization, it is possible to go so far as to sacrifice others. When it is not, only oneself (soi-meme) can be sacrificed, in the hazards of a struggle for the common dignity of man. Does the end justify the means? That is possible. But what will justify the end? To that question, which historical thought leaves pending, rebellion replies: the means. ${ }^{17}$

It is necessary to manage politics in order to preserve the only creative reality, that is man. That goes directly against contemporary nihilism, of the "everything is possible/licit", against the idea of revolt that becomes a "revolution" (here Camus criticised the Marxism of his times) or a religious attempt to totalise everything and - in so doing — destroy that same man in the name of "immediate efficacy". In fact:

It is then possible to say that rebellion, when it develops into destruction, is illogical. Claiming the unity of the human condition, it is a force of life, not of death. Its most profound logic is not the logic of destruction; it is the logic of creation. ${ }^{18}$

Thus, far from being a passive limit (just to avoid doing something), such an attitude/philosophy implies a positive, creative one. That is the reason for which-to give an example-Camus fought to create an international democracy that would guarantee to men the grounds upon which to build peaceful relationships (we are at the beginning of the cold war), or to institute a European Federation that will give to Europeans a new prospective of "justice" among peoples and individuals. For the same reasons Art assumes, in Camusian thought, a fundamental "educative" and "preparatory" value. Writing, Painting, and Playing are activities that teach the exigency to choose inside the "reality", to refuse a part of it in order to give form to the other.

16 A. Camus, Ni victimes ni bourreaux [1946], in: A. Camus, Á Combat. Éditoriaux et articles, 1944-1947, Paris: Gallimard, 2002, 670.

17 A. Camus, L’homme révolté..., 365.

18 Ibidem, 356. 
Art chooses ${ }^{19}$ and creates inside history following the exigency of freedom and dignity at the heart of every man. It operates in the same direction as the rebellion:

The procedure of beauty, which is to contest reality while endowing it with unity, is also the procedure of rebellion. Is it possible eternally to reject injustice without ceasing to acclaim the nature of man and the beauty of the world? Our answer is yes. This ethic, at once unsubmissive and loyal, is in any event the only one that lights the way to a truly realistic revolution. In upholding beauty, we prepare the way for the day of regeneration when civilization will give first place-far ahead of the formal principles and degraded values of history - to this living virtue on which is founded the common dignity of man and the world he lives in, and which we must now define in the face of a world that insults it. ${ }^{20}$

So what? How can such a thought teach us something today in an epoch in which the cult of history has been dead for a long time and in which the old revolution appears dead? Seeing things more closely in reality show us-as we saw at the beginning-that contemporary "realism", the cult of efficacy, of technocracy, is the direct offspring of the $20^{\text {th }}$ century cult of history. After the death of History — or better, of a teleological philosophy of it — what remained was the cult of strength and the attitude of political cynicism, the exaltation of what exists — of what "function" — and of the mere "fact". Such a world of post-historicism has been a world of triumphant political and moral nihilism that, after forty years, is facing a growing transnational request—or, cry—of justice. We can say to the "realist": "it's the Revolt baby!" But, as Camus taught us, hic sunt leones. Revolt in effect, following its desire of justice, can generate a return of nihilism—in a form that today looks like Manichaeism — that could be so demeasured and absolute such as was the kind of nihilism that it fought before. It can become a Revolution, following the lexicon adopted by Camus in The Rebel. The danger is that in wanting to fight the establishment, the current revolt will culminate in the huge destruction of western society, and with an aggression to those felt to be enemies (such as migrants or ethical or social groups

19 "... unity in art appears at the limit of the transformation that the artist imposes on reality. It cannot dispense with either. This correction which the artist imposes by his language and by a redistribution of elements derived from reality is called style and gives the recreated universe its unity and its boundaries. It attempts, in the work of every rebel, to impose its laws on the world, and succeeds in the case of a few geniuses. "Poets," said Shelley, "are the unacknowledged legislators of the world". Ibidem, 336.

20 Ibidem, 345. 
simply perceived as different). ${ }^{21}$ Finally, Camusian thought helps us against two different contemporary nihilisms: the living one of post-historicism and the growing one of mistrust and isolation. It teaches us that in order to achieve a new kind of politics, we have to bear the weight of a new institutional and social creation- European and International, as Camus had already sustained in the Forties 22 -without giving up the "exhausting tension" of measure.

\section{References}

Cacciari, M., Il potere che frena, Milano: Adelphi, 2013.

Camus, A., "Lettres à un ami allemand" [1945], OEuvres, Paris: Gallimard, 2013.

Camus, A., L’homme révolté, Paris: Gallimard, 1951.

Camus, A., Ni victimes ni bourreaux [1946], A. Camus, Á Combat. Éditoriaux et articles, 1944-1947, Paris: Gallimard, 2002.

Camus, A., Remarques sur la Révolte. Aa. Vv., L'existence, Paris: Gallimard, 1945.

Kojève, A., Introduction à la lecture de Hegel, Paris: Gallimard, 1947.

Kojève, A., Introduction to the Reading of Hegel, Ithaca \& London: Cornell University Press, 1969.

Rousseau, J.-J., Du Contrat Social, ou principes du droit politique, Amsterdam: Metalibri, 2008. Sharpe, M., Camus Philosophe. To return to our beginnings, Leiden, Boston: Brill, 2015.

${ }^{21}$ On the concept of establishment, see: O. Jones, The Establishment and how they get away with it, Penguin: London, 2015.

22 See: T. Visone, "International Dictatorship or International Democracy. A Discussion of Albert Camus' 1946 Considerations," in: Perspectives on Federalism, Vol. 7, Issue 2, 2015, 116-133. 